\title{
Studi Distribusi Neutronik Fluks Pada Reaktor Nuklir Sederhana
}

\author{
Isnaini Nur Islami ${ }^{1}$, Hilma Tismawati ${ }^{1}$, M. Nurul Subkhi ${ }^{2}$ \\ ${ }^{1}$ Program Sarjana Fisika, Kelompok Keilmuan Fisika Nuklir dan Komputasi, \\ Fakultas Sains dan Teknologi,Universitas Islam Negeri Sunan Gunung Djati \\ Bandung, Jl. A.H. Nasution No. 105 Bandung, Indonesia, 40614 \\ ${ }^{2}$ Laboratorium Fisika Nuklir, Kelompok Keilmuan Fisika Nuklir dan Komputasi, \\ Fakultas Sains dan Teknologi, Universitas Islam Negeri Sunan Gunung Djati \\ Bandung, Jl. A.H. Nasution No 105 Bandung, Indonesia, 40614 \\ *Penulis Penanggungjawab E-mail: isnaininurislami@gmail.com
}

\begin{abstract}
ABSTRAK
Materi dasar teknologi reaktor nuklir telah dipelajari pada kuliah fisika reaktor di jurusan fisika fakultas sains dan teknologi Universitas Islam Negeri Bandung. Tujuan utama pada penelitian ini adalah untuk mempelajari sistem perhitungan neutronik berdasarkan persamaan difusi satu dimensi serta menentukan distribusi neutron pada reaktor satu dimensi dengan menggunakan model matematika. Perhitungan ini penting dilakukan untuk menjaga kekritisan reaktor yang didasarkan kepada pengendalian reaksi fisi berantai dalam reaktor, meskipun demikian kegiatan ini tidak dapat dilakukan secara eksperimen di laboratorium. Analisis distribusi fluks neutronik dengan menggunakan Metode numerik untuk persamaan difusi satu grup dapat diaplikasikan pada reaktor nuklir sederhana. Simulasi reaktor telah dilakukan pada model reaktor satu dimensi menggunakan GUI software dan Octave. Perhitungan dilakukan dengan memvariasikan ukuran mesh atau interval dari panjang teras $(\mathrm{dx})$. Grafik distribusi fluks neutron sepanjang diameter teras diperoleh berbentuk parabola terbalik yang dapat dikatakan cukup baik dengan menggunakan tebakan fluks awal $1,25 \mathrm{E}+05 \mathrm{n} / \mathrm{cm}^{2} . \mathrm{s}$, dan k-eff 1,025 .
\end{abstract}

Kata Kunci : Simulasi; distribusi fluks neutron; k-eff; dan ukuran mesh dx. 


\begin{abstract}
The basic science technology of nuclear reactor has been used in physics courses at the Faculty of Science and Technology, State Islamic University of Bandung. The main objective of this to study the neutron calculation system based on onedimensional diffusion equations and determine the distribution of neutron in onedimensional reactors using mathematical models. This calculation is important to maintain the criticality of the reactor based on controlling chain fission reactions in the reactor, however this activity cannot be carried out experimentally in the laboratory. Analysis of neutron flux distribution using a numerical method for the diffusion equation of one group can be applied to a simple nuclear reactor. The reactor simulation was carried out on the one-dimensional reactor model using numerical calculation of GUI and Octave software. The calculation is done by varying the mesh size or interval from the core length $(\mathrm{dx})$. The neutron flux distribution calculation along core diameter which is obtained inverted parabolic curve have performed by using GUI and octave software with an initial flux of $1.25 \mathrm{E}+05 \mathrm{n} / \mathrm{cm}^{2} . \mathrm{s}$, and k-eff 1,025 .
\end{abstract}

Keywords: Simulation; distribution neutron flux; k-eff; and mesh size.

\section{Pendahuluan}

Pengetahuan dasar reaktor nuklir merupakan bagian dari mata kuliah pilihan di jurusan fisika UIN Sunan Gunung Djati Bandung. Pembahasan mengenai mata kuliah tersebut adalah dasar perencanaan dan analisis desain reaktor pada reaktor nuklir. Reaktor nuklir terjadi berdasarkan proses reaksi pembelahan inti (fisi) secara berantai dan tak terkendali. Hal ini berhubungan dengan perlunya analisis interaksi neutron dengan nuklida dan proses yang terjadi untuk mempertahankan reaksi berantai dengan cara yang stabil dan aman. Reaksi berantai tersebut berasal dari peristiwa tumbukan antara neutron dengan nuklida di dalam reaksi nuklir menyebabkan terjadinya berbagai reaksi. Dimana macroscopic cross section reaksi atau penampang lintang makroskopik diperlukan untuk mengetahui kuantitas dari masing-masing reaksi. Penampang lintang makroskopik menjadi sangat penting untuk menentukan distribusi neutron dalam teras reaktor [1]. Perhitungan neutron pada teras berbahan bakar besarnya distribusi neutron bergantung pada penampang lintang removal dan hamburan [2]. 
Percobaan simulasi ini merupakan bagian dari menggambarkan distribusi neutron dalam teras melalui perhitungan neutronik. Persamaan transport neutron merupakan persamaan perhitungan neutronik yang menggambarkan tumbukan neutron dengan bahan bakar reaktor nuklir, persamaan tersebut sangat penting dan menjadi masalah yang sangat sulit untuk menyelesaikannya dalam analisis reaktor nuklir. Akibatnya menentukan distribusi neutron dapat dilakukan dengan menggunakan persamaan difusi. Persamaan tersebut cukup sederhana memungkinkan dilakukannya perhitungan neutronik dan mempelajari konsep yang muncul dalam analisis reaktor. Karakteristik di semua neutron dalam reaktor memiliki kecepatan atau energi tunggal, dan melakukan transport dati titik ke titik sebagai proses difusi, namun tidak dapat diharapkan untuk mendapatkan hasil yang akurat [3]. Akan tetapi persamaan difusi masih menjadi metode analisis dalam desain teras reaktor untuk sementara ini [4].

Dalam kasus teras reaktor yang memiliki dimensi dan kurang memperhatikan bentuk desain geometri akan lebih cocok dilakukan dengan menggunakan persamaan difusi dibanding transport neutron yang memperhatikan besar kecilnya geometri parameter reaktor yang pengaruhnya terhadap gambaran energi [5]. Maka dari itu percobaan simulasi ini akan dilakukan dengan menggambarkan distribusi neutronik dari pesamaan difusi berdasarkan metode numerik finite difference untuk mendapatkan aproksimasi fluks neutron satu dimensi dan menerapkan hasil dari simulasi persamaan ini untuk mempelajari perilaku reaktor nuklir.

\section{Bahan dan Metoda}

Percobaan ini bertujuan untuk mempelajari sistem perhitungan dan analisis neutronik berdasarkan metode numerik finite difference untuk mendapatkan aproksimasi fluks neutron satu dimensi, serta menentukan distribusi neutron berdasarkan persamaan difusi satu dimensi dengan menggunakan model matematika yang diaplikasikan dalam GUI software seperti Matlab2014a dan Scilab-6.0.1, dan Octave.

\subsection{Persamaan Difusi Neutron Satu}

\section{Energi Satu Dimensi}

Persamaan one speed neutron difusi dapat dituliskan secara matematis yaitu :

$$
\begin{gathered}
\frac{1}{v} \frac{d \phi}{d t}=\nabla D(r) \nabla \phi(\mathrm{r}, \mathrm{t})-\sum_{\mathrm{a}}(r) \phi(r, t)+ \\
S(r, t) \ldots \ldots \ldots(1)
\end{gathered}
$$

Dimana kasus yang akan di simulasikan adalah fluks yang tidak bergantung pada waktu karena untuk reaktor kritis yang dimana produksi 
dan hilangnya neutron seimbang sehingga fluks neutron akan konstan sepanjang waktu, maka turunan waktu nya adalah 0 . Maka persamaan (1) menjadi :

$$
\begin{array}{r}
S(r)=-D \nabla^{2} \phi(\mathrm{r})+\sum_{a} \cdot(r) \phi(r) \\
S(x)=-D \frac{d^{2} \phi}{d x^{2}}+\sum_{a} .(x) \phi(x) \ldots \ldots \ldots
\end{array}
$$

Karakteristik kondisi batas pada finite slab dengan panjang a dengan mengabaikan panjang ekstrapolasi :

$$
\phi(0)=\phi(a)=0
$$

Kemudian kita akan mendiskritisasi panjang slab x pada $\mathrm{N}+1$ dengan perbedaan jarak tiap titik diskrit $\Delta=d x$

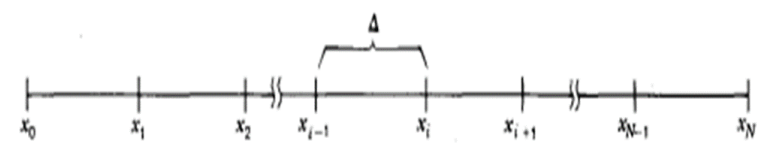

Kemudian persamaan (2) dibuat sesuai masing-masing titik diskrit $\mathrm{x}_{\mathrm{i}}$, tetapi sebelumnya aproksimasi untuk $\frac{d^{2} \phi}{d x^{2}}$ melalui persamaan taylor untuk mendapatkan nilai $\phi$ pada $\mathrm{x}_{\mathrm{i} \pm 1}$ di daerah titik $\mathrm{x}_{\mathrm{i}}$ :

$$
\begin{gathered}
\phi_{i+1} \equiv \phi\left(x_{i+1}\right)=\phi_{i}+\left.\Delta \frac{d \phi}{d x}\right|_{i}+\left.\frac{\Delta^{2}}{2} \frac{d^{2} \phi}{d x^{2}}\right|_{i} \\
+\cdots \\
\phi_{i-1} \equiv \phi\left(x_{i-1}\right)=\phi_{i}-\left.\Delta \frac{d \phi}{d x}\right|_{i}+\left.\frac{\Delta^{2}}{2} \frac{d^{2} \phi}{d x^{2}}\right|_{i}-\ldots
\end{gathered}
$$

Kemudian jumlahkan persamaan $\phi_{i+1}$ dan $\phi_{i-1}$ dan didapatkan persamaan:

$$
a \phi_{i-1}+\phi_{i-1}=2 \phi_{i}+\left.\Delta^{2} \frac{d^{2} \phi}{d x^{2}}\right|_{i}
$$$$
\left.\frac{d^{2} \phi}{d x^{2}}\right|_{i} \cong \frac{\phi_{i-1}-2 \phi_{i}+\phi_{i-1}}{\Delta^{2}} \ldots \ldots
$$

Kemudian substitusi persamaan (4) ke dalam persamaan (2) pada titik daerah titik $\mathrm{x}_{\mathrm{i}}$, dan didapatkan persamaan :

$-D\left(\frac{\phi_{i-1}-2 \phi_{i}+\phi_{i-1}}{\Delta^{2}}\right)+\sum_{a} \cdot \phi_{i}=S_{i} \quad ; i=1,2, \ldots$

Dimana kita mendefinisikan $S_{i} \equiv S\left(x_{i}\right)$ sehingga persamaan diferensial diatas menjadi :

$\frac{-D}{\Delta^{2}} \phi_{i-1}+\left(\frac{2 D}{\Delta^{2}}+\Sigma_{-}\right) \phi_{i}-\frac{D}{\Delta^{2}} \phi_{i+1}=S_{i}$

Dimana $\frac{-D}{\Delta^{2}}=\alpha$ dan $\frac{2 D}{\Delta^{2}}+\sum_{a \cdot}=\beta$ sehingga persamaannya menjadi :

$\alpha_{i} \phi_{i-1}+\beta_{i} \phi_{i}+\alpha_{i} \phi_{i+1}=S_{i} \quad ; i=1, \ldots, N-1$.

Kemudian memecahkan $\phi_{i}$ yang didiskritisasi, agar lebih eksplisit, pertama buat persamaan (7) secara mendetail :

$$
\begin{aligned}
\beta_{1} \phi_{1}+\alpha_{1} \phi_{2} & & S_{1} \\
\alpha_{2} \phi_{1}+\beta_{2} \phi_{2}+\alpha_{2} \phi_{3} & & S_{2} \\
\alpha_{3} \phi_{2}+\beta_{3} \phi_{3}+\alpha_{3} \phi_{4} & & S_{3}
\end{aligned}
$$

$\phi_{N-2}+\beta_{N-1} \phi_{N-1}=S_{N-1}$

(8) 
Kemudian persamaan (8) diubah menjadi persamaan matriks :

$$
\begin{aligned}
& \left.\begin{array}{lllll}
\beta_{1} & \alpha_{1} & & & \\
\alpha_{2} & \beta_{2} & \alpha_{2} & & \\
& \alpha_{3} & \beta_{3} & \alpha_{3} & \\
& & \alpha_{4} & \beta_{4} & \alpha_{4}
\end{array}\right) \\
& \left(\begin{array}{c}
\phi_{1} \\
\phi_{2} \\
\phi_{3} \\
\phi_{4} \\
\vdots \\
\phi_{N-1}
\end{array}\right)=\left(\begin{array}{c}
S_{1} \\
S_{2} \\
S_{3} \\
S_{4} \\
\vdots \\
S_{N-1}
\end{array}\right) \\
& A \phi=S \quad \ldots \ldots
\end{aligned}
$$

Dimana $\phi$ dan S adalah (N-1) dimensi kolom vektor dan A adalah (N-1) x (N1) berupa matriks diagonal. Dan solusi untuk mencari $\phi$ yaitu dengan menginverskan matriks A sehingga persamaanya menjadi :

$$
\phi=A^{-1} S \quad \ldots \ldots(10)
$$

\subsection{Metode Ekspansi Fungsi Eigen}

Fungsi Eigen dapat didefinisikan sebagai normal modes dan therminologi yang sering dibawa dalam analisis reaktor. Persamaan umum untuk menentukan distribusi flux neutron dari distribusi sumber neutron dengan finite slab selebar a yaitu :

$$
\begin{aligned}
\frac{d^{2} \phi}{d x^{2}}-\frac{1}{L^{2}} \phi(x) & =\frac{S(x)}{D} \quad ;-\frac{a}{2}<x \\
& <\frac{a}{2} \quad \ldots(11)
\end{aligned}
$$

$$
\frac{d^{2} \psi}{d x^{2}}+B^{2} \psi(x)=0
$$

Dimana $\mathrm{B}^{2}$ hanya arbitrary parameter dan permasalahan homogen ( satu energi) persamaan umum menjadi

$$
\begin{gathered}
\psi(x)=A_{1} \cos B_{x}+A_{2} \sin B_{x} \quad ; \\
B=\frac{n \pi x}{a} \quad \ldots(12)
\end{gathered}
$$

Dan solusi fungsi eigen

$$
\begin{aligned}
& \psi_{n}(x) \\
& = \begin{cases}A_{n} \cos \frac{n \pi x}{a} & ; n=1,3,5 \ldots \\
A_{n} \sin \frac{n \pi x}{a} & ; n=2,4,6, \ldots\end{cases}
\end{aligned}
$$

Fungsi eigen yang berperilaku baik dipresentasikan sebagai kombinasi linear pada $\mathrm{f}(\mathrm{x})$. Dalam hal ini representasi hanya untuk kepentingan formal kecuali jika adanya cara menentukan koefisien ekspansi.

$$
f(x)=\sum_{n=1}^{\infty} c_{n} \psi_{n}(x)
$$

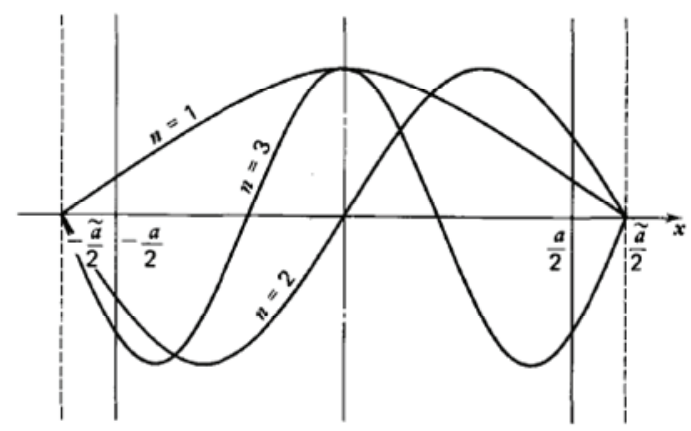

Gambar 1 Fungsi eigen untuk geometri slab [3] 
Penelitian yang dilakukan oleh Ferrandiz dkk, 2017 [6] dalam mencari solusi permasalahan nilai batas pada perencanaan dan analisis desain reaktor, memanfaatkan dengan mencari solusi sebagai fungsi eigen. Penelitiannya secara analitik untuk perencanaan desain reaktor untuk mengetahui bentuk distribusi neutron dapat dilakukan dengan metode ekspansi fungsi eigen ini.

\subsection{Percobaan Simulasi}

Percobaan simulasi ini dilakukan dengan model matematika persamaan difusi neutron satu grup satu dimensi dengan menggunakan GUI software dan Octave. Diperlihatkan langkah percobaan simulasi pada gambar 2 dengan menginput parameter yang ada pada tabel 1 .

Input parameter dalam toolbox GUI software yang telah dibuat sedangkan pada software Octave, penginputan secara langsung pada command window karena tidak tersedianya pembuatan toolbox GUI. Kemudian akan didapatkan parameter baru yaitu $\sum_{a}, \sum_{f}, v \sum_{f}$ Kemudian menginput parameter-parameter pada persamaan difusi neutron slab satu energi satu dimensi.
Tabel 1 Input Parameter yang digunakan dalam simulasi persamaan difusi satu grup satu dimensi

\begin{tabular}{ll}
\hline \multicolumn{2}{c}{ Parameter Input } \\
\hline Densitas U-235* & $1,909 \mathrm{E}-4 \mathrm{~cm} / \mathrm{b}$ \\
\hline Koefisien difusi & $9,21 \mathrm{~cm}$ \\
$(\mathrm{D})^{* / * * *}$ & \\
\hline Panjang teras & $250 \mathrm{~cm}$ \\
\hline Fluks awal & $125000 \mathrm{n} / \mathrm{cm}^{2} \mathrm{~s}$ \\
\hline k-eff & 1,025 \\
\hline Penampang & $484 \mathrm{~b}$ \\
lintang & \\
mikroskopik \\
absorpsi $\left(\sigma_{a}\right)^{*}$ \\
\hline Penampang \\
lintang \\
mikroskopik fisi \\
$\left(\sigma_{a}\right)^{*}$ \\
\hline Banyaknya \\
neutron \\
hasil fisi $\left(\sigma_{a}\right)^{*}$ \\
\hline
\end{tabular}




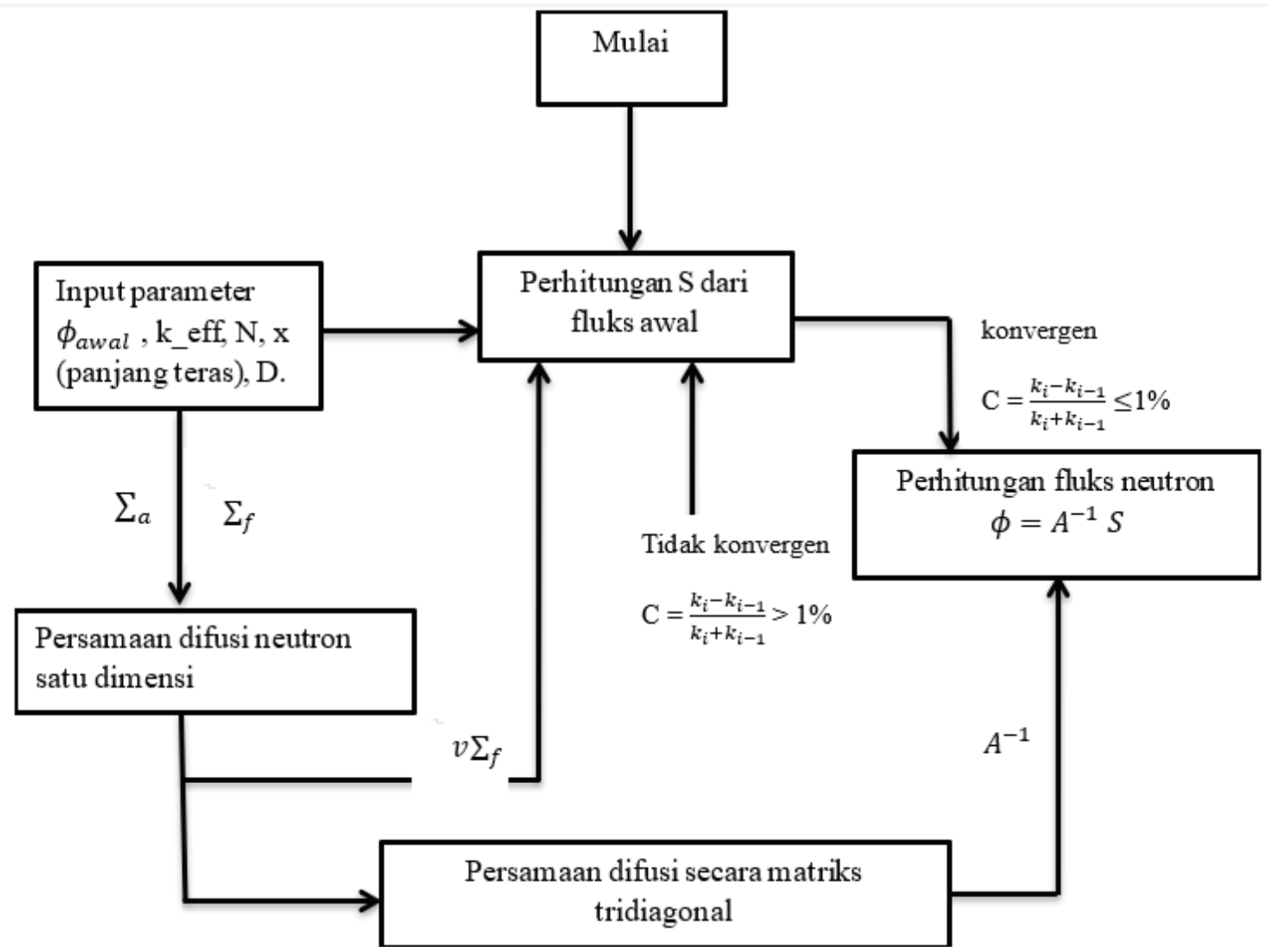

Gambar 2 Diagram alir percobaan simulasi pada software

Kemudian parameter yang telah didapatkan yaitu $\sum_{a}$, akan digunakan untuk menghitung komponen $\beta_{i}$ pada persamaan (7). Sedangkan komponen $\alpha_{i}$ didapatkan dari hasil input koefisien difusi pada reaktor dibagi dengan interval $\mathrm{dx}$ kuadrat yang menjadi jarak antar masing-masing titik diskrit. Setelah itu variabel komponen $\alpha_{2}$ dan $\beta_{i}$ di masukan dalam persamaan matriks tridiagonal seperti persaman (9). Karena tujuannya adalah mengetahui pola distribusi neutronnya sehingga matriks A pada persamaan (9) dilakukan proses invers matriks $A^{-1}$ untuk mendapatkan nilai fluks. Kemudian hasil input pun menghasilkan parameter $v \sum_{f}$ dari perkalian $\mathrm{v}$ dengan $\sum_{f}$ yang nantinya digunakan untuk mendapatkan nilai sumber $\mathrm{S}$ awal dengan mengkalikan parameter $v \sum_{f}$ dengan nilai fluks awal tebakan dibagi dengan k-eff yang diinput pada toolbox GUI software.

Setelah didapatkan nilai $\mathrm{S}$ dari fluks awal tebakan dan matriks invers tridiagonal $\mathrm{A}^{-1}$, maka selanjutnya adalah menghitung nilai fluks dengan mengunakan persamaan (10). Kemudian jika hasilnya tidak konvergen maka perhitungan tersebut diulangi ke proses perhitungan $\mathrm{S}$ dengan mengunakan nilai fluks $\phi$ tersebut sampai mendapatkan nilai yang konvergen. 


\section{Hasil dan Pembahasan}

Pada simulasi sederhana ini menghasilkan gambar 3 terlihat grafik panjang teras dengan variasi interval $d x$ terhadap fluks pada GUI software dan Octave berbentuk parabola terbalik. Perhitungan neutron pada teras berbahan bakar besarnya fluks bergantung pada penampang lintang removal, dalam artian penampang lintas absorpsi. Jika grafik bentuk parabola terbalik pada gambar 3 ditinjau dari penampang lintang makroskopik maka yang berperan dalam percobaan ini adalah makroskopik penampang lintang removal/transfer dan penampang lintang absorpsi/penyerapan. Dimana penampang lintang removal tersebut menunjukan besarnya neutron mengalami kebocoran keluar teras dikarenakan tidak adanya reflektor yang memantulkan neutron ketika terjadi hamburan. Maka penampang lintang makroskopik absorpsi ataupun removal pada siklus tengah sangat kecil dibandingkan dengan siklus sebelum dan sesudahnya kerena populasi fluks di siklus tengah sangat banyak sehingga terbentuknya puncakkan.

Kemudian jika bentuk grafik parabola terbalik tersebut ditinjau dari efek reaktivitas yang berhubungan dengan perubahan komposisi bahan bakar. Proses burn up bahan bakar mengakibatkan berkurangnya jumlah inti bahan bakar dan menghasilkan inti bahan bakar dan menghasilkan produk fisi yang memiliki penampang lintang menangkap neutron dan biasanya transmutasi isotop fertil ke isotop fisil memiliki efek reaktivitas positif. Proses transmutasi umumnya menghasilkan lebih banyak inti fisil daripada menghancurkan di awal siklus, menyebabkan efek reaktivitasnya positif sampai konsentrasi inti fisil yang ditransmisikan masuk dalam keadaan kesetimbangan. Dan dalam percobaan simulasi ini karena bahan bakarnya menggunakan U-235 dan U-238 maka dianalisis bahwa terjadinya penumpukan $\mathrm{Pu}-239$ di awal reaktor hidup dengan menghasilkan reaktivitas positif yang lebih besar daripada efek reaktivitas negatif dari besarnya penipisan inti U-235 dan U-238. Namun, konsentrasi Pu-239 akan mengalami nilai kejenuhan yang ditentukan oleh kesetimbangan antara tingkat transmutasi U-238 dan tingkat deplesi $\mathrm{Pu}-239$, dimana hal itu akan terjadi penipisan U-235 dan penumpukan produk fisi yang tinggi dan menghasilkan efek reaktivitas negatif yang tinggi selama masa pakai bahan bakar reaktor. Kemudian pada siklus akhir terjadinya penumpukan aktinida (unsurunsur yang bersifat radioaktif) sehingga terjadinya perubahan reaktivitas bahan bakar karena beberapa aktinida tersebut bertindak sebagai penyerap neutron. Maka siklus akhir akan menurunkan distribusi fluks neutron karena adanya proses penyerapan neutron oleh beberapa aktinida hasil produk fisi dan peluruhan nuklida produk fisi. 
Reaktor dengan komposisi material yang fixed dalam panduan kursus Techical University Dresden, kondisi kritis menunjukan reaktor pada ukuran minimum, yang ditentukan sebagai kehilangan neutron oleh kebocoran yang dikompensasikan secara tepat oleh neutron di dalam teras. Begitu pun bentuk dari distribusi neutron untuk finite slab akan

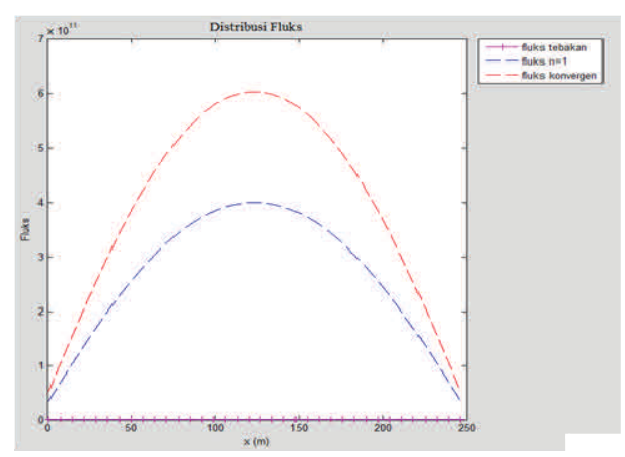

(a)

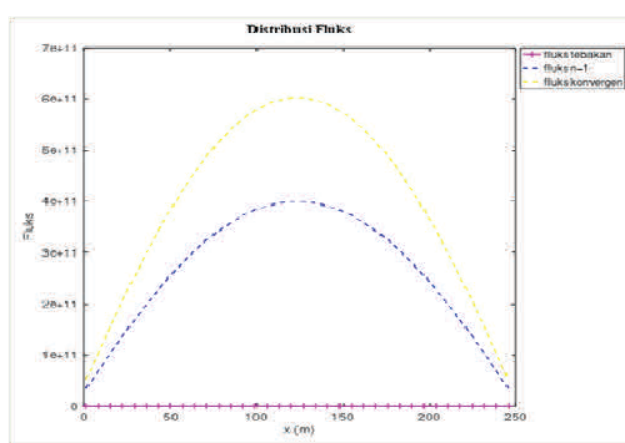

(b)
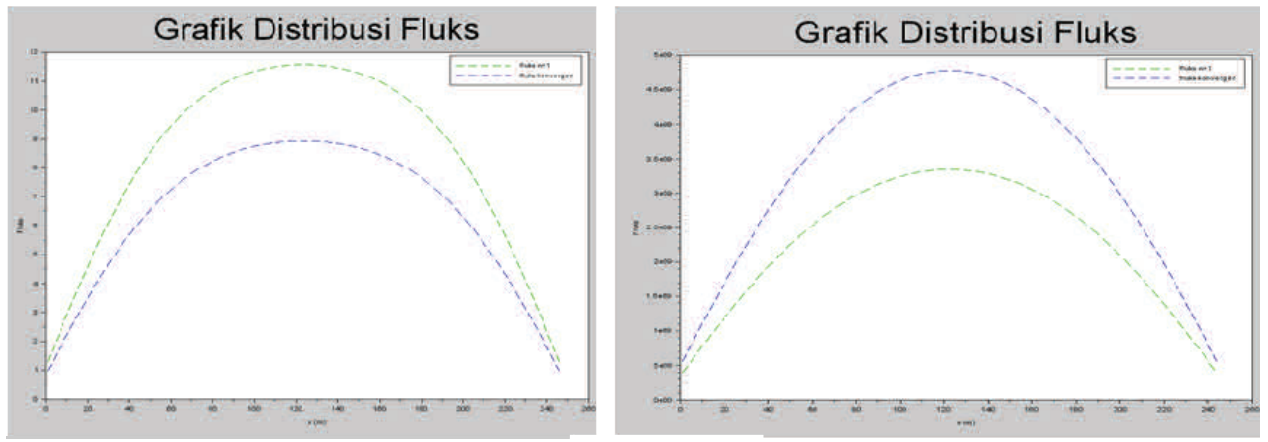
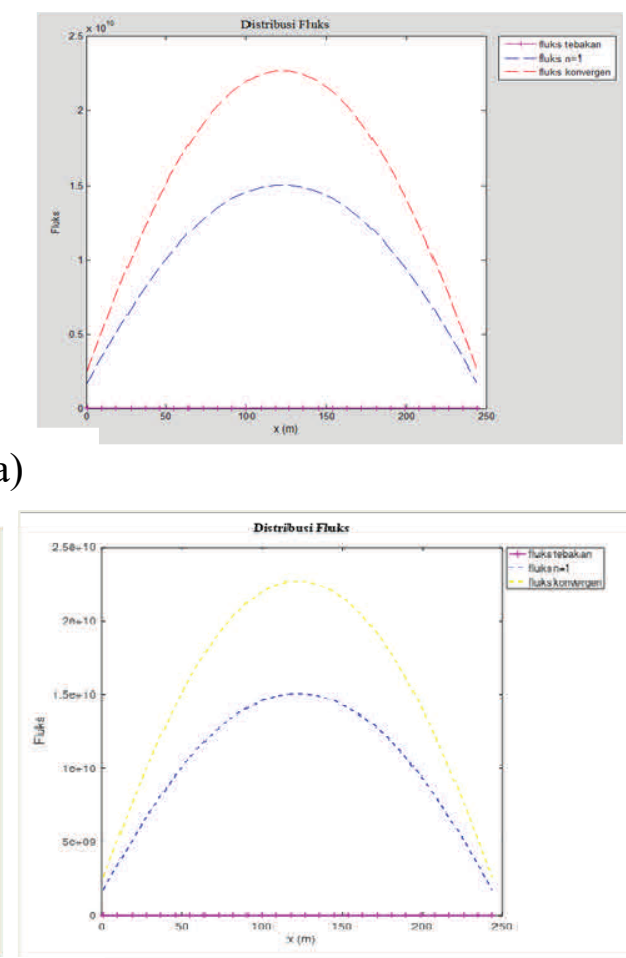

(c)

turun dekat dengan batas yang diakibatkan kebocoran neutron. Maka simulasi ini telah sesuai dengan referensi karena menunjukan bentuk distribusi fluks neutron pada kedua sisi ujung fluks neutronnya menurun mendekati batas. Hal itu dikarenakan adanya kompensasi oleh neutron di dalam teras melalui kebocoran neutron.

Gambar 3 Grafik panjang teras arah aksial terhadap fluks neutron dengan memvariasikan interval $d x$ pada $d x=7 d a n d x=9$ pada software (a) Matlab2014a, (b) Octave, dan (c) Scilab-6.0.1. 
Reaktor dengan komposisi material yang fixed dalam panduan kursus Techical University Dresden, kondisi kritis menunjukan reaktor pada ukuran minimum, yang ditentukan sebagai kehilangan neutron oleh kebocoran yang dikompensasikan secara tepat oleh neutron di dalam teras. Begitu pun bentuk dari distribusi neutron untuk finite slab akan turun dekat dengan batas yang diakibatkan kebocoran neutron. Maka simulasi ini telah sesuai dengan referensi karena menunjukan bentuk distribusi fluks neutron pada kedua sisi ujung fluks neutronnya menurun mendekati batas. Hal itu dikarenakan adanya kompensasi oleh neutron di dalam teras melalui kebocoran neutron.

Kemudian bentuk grafik yang dihasilkan dari simulasi ini yaitu parabola terbalik ini pun telah sesuai dengan fungsi eigen untuk geometri slab dengan $n=1$ seperti pada gambar 1 dalam metodologi penelitian. Dimana fungsi eigen bisa didefinisikan sebagai mode normal dan terminologi yang sering dibawa dalam analisis reaktor dalam pemecahan nilai batas.

Grafik pada gambar 3 dengan menggunakan GUI software dan Octave didapatkan nilai rasio untuk kemiringan dari distribusi fluks neutron. Pengamatan dari hasil nilai rasio $\Phi_{\text {tertinggi }}$ dan $\Phi_{\text {rata-rata }}$ dari software-software yang digunakan pada tabel 2, bahwa semakin kecil nilai interval teras arah aksial $\mathrm{dx}$ maka semakin besar nilai rasio $\Phi_{\text {tertinggi }}$ dan $\Phi_{\text {rata-rata }}$ nya. Dan semakin kecil mesh atau jarak tiap titik pada teras arah aksial maka akan lebih akurat berdasarkan metode diskritisasi matematika. Dimana hal itu menunjukan bahwa semakin diperkecil ukuran mesh maka semakin baik kemiringan, karena kemiringan tersebut menggambarkan kondisi reaktor berisi bahan bakar saja pada teras yang belum diberikan moderator, dan bahan-bahan lainnya.

Kemudian didapatkan pula nilai k-eff hasil iterasi akhir yaitu 1,543. Hal tersebut menggambarkan bahwa reaktor dalam kondisi super kritis. Jika ditinjau dari nilai k-eff yang didapat sangat jauh dari batas kritisnya yaitu k-eff sama dengan 1. Dan meningkatnya k-eff dapat diakibatkan oleh modifikasi ukuran teras reaktor atau konsentrasi bahan fisi. Walaupun pada simulasi ini kenaikan k-eff terjadi bukan memodifikasi atau memvariasikan ukuran teras reaktornya namun memvariasikan mesh atau ukuran interval teras dx. Dan juga wajar jika nilai k-eff lebih besar dari satu karena kemiringan dari bentuk distribusi fluks neutronnya pun tinggi. 
Tabel 1 Nilai rasio fluks tertinggi dan rata-rata pada hasil variasi ukuran mesh $\mathrm{dx}$

\begin{tabular}{cccc}
\hline $\begin{array}{c}\text { Variasi dx } \\
(\mathrm{cm})\end{array}$ & $\phi_{\text {tertinggi }}$ & $\phi_{\text {rata }- \text { rata }}$ & Rasio $\frac{\phi \text { tertinggi }}{\text { prata-rata }}$ \\
\hline 9 & $2,2671 \mathrm{E}+10$ & $21,3551 \mathrm{E}+10$ & $0,1062 \mathrm{E}+10$ \\
8 & $1,1860 \mathrm{E}+11$ & $13,3103 \mathrm{E}+11$ & $0,8910 \mathrm{E}+10$ \\
7 & $6,0240 \mathrm{E}+11$ & $66,3226+11$ & $0,9082 \mathrm{E}+10$ \\
6 & $7,0215 \mathrm{E}+12$ & $96,5111 \mathrm{E}+12$ & $7,2753 \mathrm{E}+10$ \\
5 & $1,8293 \mathrm{E}+14$ & $29,7444 \mathrm{E}+14$ & $615 \mathrm{E}+10$ \\
\hline
\end{tabular}

\section{Kesimpulan}

Persamaan difusi satu grup satu dimensi berdasarkan metode numerik finite difference untuk mendapatkan aproksimasi fluks neutron, dilakukan dengan menginput nilai tebakan fluks awal $1,25 \mathrm{E}+05 \mathrm{n} / \mathrm{cm}^{2} . \mathrm{s}$, densitas atom U-235 1,909E-4 cm. b $^{-1}$, koefisien difusi 9,21 cm, panjang teras arah aksial (x) $250 \mathrm{~cm}$ dan k-eff 1,025. Berdasarkan hasil percobaan simulasi dengan GUI software dan Octave dengan memvariasikan nilai interval panjang teras $\mathrm{dx}$ didapatkan grafik berbentuk parabola terbalik dan hasil analisisnya bahwa semakin besar ukuran mesh atau interval teras $\mathrm{dx}$ arah aksial maka semakin kecil rasio kemiringan dari distribusi fluks neutron yang didapatkan. Dan nilai k-eff hasil iterasi akhir 1,543 yang menggambarkan reaktor sederhana ini dalam kondisi super kritis.

Percobaan simulasi ini perlu adanya tinjauan lanjut untuk distribusi fluks pada daerah reflektor yang nantinya akan mempengaruhi bentuk distribusi fluks neutron pada daerah teras reaktor. Dan perlu juga adanya tinjauan lanjut mengenai simulasi model matematika persamaan difusi untuk 2 dimensi, 3 dimensi, dan multigroup.

\section{Referensi}

1. Shafii, M. A. (2015). Perhitungan Penampang Lintang Mikroskopik dalam Sel Bahan Bakar Nuklir. Spektra: Jurnal Fisika dan Aplikasinya, 16(1), 23-27.

2. Sunarto, R. U. (2013). Desain Reaktor Air Superkritis (Supercritical Water Reactor) dengan Bahan Bakar Thorium.

3. Duderstadt, J. J. (1976). Nuclear reactor analysis. Wiley.

4. Tahara, Y., \& Sekimoto, H. (2002). Transport equivalent diffusion constants for reflector region in PWRs. Journal of nuclear science and technology, 39(7), 716-728.

5. Shafii, M. A. (2013). Solution methods of neutron transport equation in 
nuclear reactors. Jurnal Ilmu Dasar, 14(2), 59-65.

6. Vidal-Ferràndiz, A., Carlos, S., \& Verdú, G. (2017). Estudio del flujo neutrónico en un reactor cilíndrico. Modelling in Science Education and Learning, 10(2), 5-20.

7. Hansen, W., \& Wolf, T. (2009). Complete refurbishment of the AKR training reactor of the Technical University Dresden. Modernization and Refurbishment, 61.

8. Stacey, W. M. (2007). Nuclear reactor physics (Vol. 2). Berlin: Wiley-Vch. 